\title{
Thinking Otherwise in a Culture of Anxiety and Fear
}

\section{Michal Kobialka}

In the post-2001 culture of anxiety and fear, when Anglo-American practicality and expediency are used not only to fight the global war on terrorism, but also to camouflage the forces that define and set the limits to what is possible and can be done; when we are faced daily with an increasingly sophisticated infrastructure of surveillance, intervention, and control; and when the temporality of the state of emergency is transformed into a spatial arrangement inhabited by many of us who refuse to be inscribed into that order, thinking radically about the practices in the field of theatre or performance studies, or questioning and probing the representational/performative order of things, is the only recourse.

Over the years and under John Gronbeck-Tedesco's editorship, the Journal of Dramatic Theory and Criticism provided many of us with a space where we could explore how we critically and physically/performatively relate to what is going on. I am grateful for the opportunity to investigate (with Rose Bank) the emergent spatial historiography at that time when history and archival research were still dominated by disciplinary identifications with the von Rankean model-see, for example, JDTC (Spring 1989) and JDTC (Spring 1991).

Without this space; without a critique of the current condition, without the shift in how history is thought about within the structures of the discipline/institution, and without actively seeking another praxis, the field of theatre/performance studies would lose an important site yielding new insights into this historiography, which exists to expose social formations and the production of knowledge in our field. Journal of Dramatic Theory and Criticism has always existed for me as a place that allowed many of us to take exception to the prevailing academic order of things, so that we/I can think "otherwise."

Thank you, John.

\footnotetext{
Michal Kobialka is Chair and Professor of Theatre in the Department of Theatre Arts \& Dance at the University of Minnesota. He is the author of a book on Tadeusz Kantor's theatre, A Journey Through Other Spaces: Essays and Manifestos, 1944-1990 (1993) and on the early medieval drama and theatre, This Is My Body: Representational Practices in the Early Middle Ages (1999); an editor of Of Borders and Thresholds: Theatre History, Practice, and Theory (1999); a co-editor (with Barbara Hanawalt) of Medieval Practices of Space (2000); as well as of more than 65 articles, essays and reviews. His new book on Tadeusz Kantor will be published by University of Minnesota Press in 2008.
} 